\title{
La liturgia profanada desde la modernidad. Teatralización y desplazamiento de lo sacro
}

The profanated liturgy since modernity. Theatralization and displacement of the sacred

Julio César Moreno Moreno

ETSAM. Universidad Politécnica de Madrid, España cesar@jcesar.org

https://orcid.org/0000-0001-6986-6716 


\title{
Resumen
}

Los grandes cambios que experimentaron los espacios de la liturgia católica durante buena parte del siglo XX estuvieron ligados a las transformaciones que se dieron paralelamente en los espacios de representación del teatro occidental. La correlación de los cambios tuvo que ver con cómo cada uno de los dos ámbitos entendía su propio origen, y con el papel identitario que le concedió.

Esas alteraciones en la espacialidad de la liturgia y del teatro tienen mucho en común, pero lo que caracteriza esas similitudes es que se pueden interpretar como "profanaciones", en el sentido que le da Giorgio Agamben al término. La profanación neutralizaría las separaciones base de las antiguas organizaciones espaciales, propiciando el desplazamiento de las funciones. En todo ello, se puede detectar una creciente apropiación del espacio por parte de los participantes - incluidos público y fieles-y una cierta exaltación del movimiento de sus cuerpos en ese espacio, con claras implicaciones políticas.

El objetivo de este artículo es evidenciar que la vez que se ha producido esta incorporación de lo profano a los espacios tradicionales de la liturgia, lo sagrado ha trascendido los límites de los templos hace ya varias décadas, en un proceso que se ha acelerado en nuestros días al pasar de lo analógico a lo digital.

Palabras clave: Liturgia; Iglesias; teatros; profanación; función arquitectónica

\begin{abstract}
The great changes developed in the spaces related to the catholic liturgy for most of the 20th century were tied to the transformations that, adjunctly, took place in the spaces dedicated to occidental theatrical enactment. The correlation of changes had to do with the way each field perceived its own origin and the identity role they assigned to it.

The changes developed in the liturgic and theatrical spaces have a lot in common, but what mainly characterizes those similarities is the fact that they can be read as "profanations" within the sense of Giorgio Agamben. Profanation neutralizes the seminal separations in antique spatial organizations, thus favouring the function displacement. Through all this, it can be detected an increasing appropriation of space by the participants -including the audience and the worshippers- also a kind of exaltation of their body movements within that space that has clear political implications.

The purpose of this paper is to show that while the inclusion of the profane into the traditional spaces of the liturgy took place, the concept of sacral transcended the limits of temples several decades ago during a process that has been speeding up nowadays when society is moving from analogic to digital.
\end{abstract}

Key words: liturgy; churches; theatres; profanations; architectural function

Para citar este artículo / To cite this article:

MORENO, J.C.. La liturgia profanada desde la modernidad. Teatralización y desplazamiento de lo sacro. En:[i2] Investigación e Innovación en Arquitectura y Territorio [en línea]. 2021, Vol. 9, Núm. 2, pp. 107-130. ISSN: 2341-0515. https://doi.org/10.14198/I2.17562

Este trabajo se publica bajo una licencia de Creative Commons Reconocimiento 4.0 Internacional (CC BY 4.0): https://creativecommons.org/licenses/by/4.0/deed.es_ES 


\section{Introducción}

La relación entre lo sagrado y el teatro es muy antigua en occidente. De hecho, está comúnmente aceptado que el teatro tuvo un origen religioso - también que es un rasgo que comparten una mayoría de culturas- y que esa relación llega hasta el presente en ritos y en fiestas sagradas, en una suerte de pervivencia de un preteatro. Ese teatro primitivo, caracterizado por la integración de múltiples elementos opuestos ${ }^{1}$-lo profano y lo sagrado o la tragedia y la comedia, entre otros muchos- sería el que habría dado lugar más tarde al teatro propiamente dicho. Aunque el teatro nació como rito y mantuvo parte de su carácter sagrado hasta los tiempos de la Roma paleocristiana, la relación del cristianismo con el teatro en ese momento fue de total rechazo y condena, y como consecuencia estuvo prohibido hasta el siglo IX. La relación desde entonces, aunque con altibajos, nunca ha sido del todo fluida.

Esa situación, de por sí paradójica, lo es más si tenemos en cuenta que la liturgia de la misa católica tiene desde su origen unas componentes de representación teatral, en cuanto a que se reproducían las palabras de Jesús en la última cena. La explicación de esa paradoja parece estar en la falta de sintonía de la Iglesia con lo que quedaba del teatro grecolatino, por la fase de decadencia a la que este había llegado. Pese a ello, a lo largo de los siglos ese teatro fue calando en el cristianismo, llegando incluso a producir más tarde un teatro cristiano (Rodríguez Adrados 1994, p. 17). Este teatro, una vez emancipado de la religión dio lugar al teatro occidental cuyo tipo arquitectónico representativo sería la sala a la italiana, que desde el Renacimiento hasta finales del siglo XIX evolucionó hasta ser la perfeccionada máquina que en muchos aspectos sigue aún vigente. Aparte de la sofisticación de todo el aparataje escénico, había llegado a ser un fiel reflejo de la sociedad y del gusto burgués, con sus repartos espaciales jerarquizados según clases sociales y con delimitaciones muy claras sobre lo que a cada uno de los asistentes le estaba permitido hacer. (Ladra, David en Navarro de Zuvillaga 1997, p. 39)

En cuanto a los tipos espaciales asociados a la liturgia católica, en los primeros tiempos del cristianismo las misas se celebraban en pequeños grupos que se reunían en las viviendas de algunos patricios, las llamadas domus ecclesiae. De ahí se pasó a las primeras basílicas, que eran espacios sencillos de tamaño reducido. A partir de entonces, las misas se fueron haciendo más complejas y artificiosas, así como los espacios de culto, que pronto serían las grandes basílicas romanas. En estos espacios estarían ya reflejadas las jerarquías eclesiásticas mediante claras separaciones espaciales. Así, de las primeras celebraciones de pocas personas reunidas en torno a una mesa o altar se pasó a misas con un mayor número de participantes, segregados en partes bien diferenciadas de grandes espacios como las basílicas de la época de Constantino. Las catedrales medievales y las iglesias renacentistas $\mathrm{y}$ - aunque de manera diferente — las iglesias barrocas mantuvieron las divisiones espaciales, y en las misas se siguió demandando una escasa participación de los fie-

\footnotetext{
1 “¿dónde surgió, dónde está documentado el preteatro? Podríamos responder: en todas las sociedades agrarias que celebraban estas fiestas. Está en ellas mezclado con elementos no miméticos, orales o no, muy diversos. Lo que ha hecho el teatro es elegir, combinar, sintetizar, dar nuevo sentido; y crear piezas y piezas con una nueva originalidad." (Rodríguez Adrados 1994, p. 13)
} 


\section{les en los oficios religiosos. ${ }^{2}$}

Por tanto, al inicio de la modernidad se contaba con unos tipos arquitectónicos asociados al teatro y la liturgia que, durante siglos, habían evolucionado hacia la separación entre categorías de participantes, complicando mucho las ceremonias y las representaciones, y relegando, con el tiempo, a un papel pasivo tanto a los fieles como al público del teatro. A medida que se desarrollaba la modernidad — pero sobre todo con su crisis y su finalestas situaciones demandaban profundos cambios. El desarrollo de disciplinas como la arqueología o la historia, o el auge de los movimientos revisionistas del pasado, los historicismos, propiciaron una vuelta a los orígenes para definir sus nuevas configuraciones, encontrando el rito sagrado en el origen del teatro y la escenificación de la última cena en el de la liturgia.

\section{Teatralización de la liturgia y sacralización del teatro}

Los cambios en los espacios y en las celebraciones del teatro y la liturgia católica se sucedieron a lo largo del siglo XX con importantes coincidencias, que dejan ver una interrelación entre ellos. Es especialmente significativa la simultaneidad en dos momentos clave, que además coincidieron con las dos vanguardias artísticas. El primero se dio en el periodo de entreguerras, con el teatro de vanguardia de Antonin Artaud por un lado y con los primeros frutos del Movimiento Litúrgico por otro. En el segundo momento, que se produjo en la segunda vanguardia, coincidieron por un lado el desarrollo de una rama del teatro de vanguardia que se ritualizó y sacralizó en profundidad y, por otro, los cambios en la liturgia asociados al Concilio vaticano II. Sin embargo, los pasos previos no estuvieron tan sincronizados.

En el caso de los precedentes de esta situación en los teatros, hubo planteamientos muy críticos desde la Ilustración, con profundos cambios en la organización espacial. De ellos, el teatro de Besançon de Louis Etienne Ledoux fue la primera propuesta construida. Su proyecto se englobaba en una idea más ambiciosa de renovación de la disciplina teatral, con serias implicaciones para la sociedad. Hasta tal punto creía en los beneficios sociales de ese teatro renovado, que veía en él “una nueva religión”. Incorporó en Besançon algunos cambios que dejarían profunda huella en la futura evolución de los teatros, como la desaparición de los palcos cerrados o la invención del foso para la orquesta. También, en mayor o menor medida, esas novedades tendrían sus equivalencias más adelante en unos espacios de culto católico, porque ayudarían a adecuarlos a las demandas de la sociedad moderna. Interesa señalar que facilitaron una relación más directa y cercana entre actores y público o una visibilidad casi "panóptica", desde una colocación del conjunto de asistentes y oficiantes más igualitaria, democrática y dinámica. (Vidler 1994, p. 95) (Fig.1)

\footnotetext{
2 Plazaola critica que desde ese momento la evolución de los espacios de la liturgia, porque en ellos se pierde "la adhesión ingenua y natural al contenido objetivo de la liturgia" y se va imponiendo un creciente gusto por el espectáculo: "De la Domus Ecclesiae primitiva y la basílica sencilla y orgánica, elemento funcional dentro de un complejo eclesiástico (bautisterio, catecumenado, schola, etc.), se pasó, a través de la iglesia abacial, a la gran iglesia medieval. [...] La grandiosidad y el esplendor de la arquitectura gótica se prestó entonces para satisfacer el natural gusto por el espectáculo.” (Plazaola 1965, p. 70)
} 
Sin embargo, hubo que esperar a que la Revolución de Octubre propusiera la ruptura radical con la tradición teatral en las salas a la italiana. Los grandes cambios políticos y sociales así lo demandaban, de manera que incluso al principio aquel proletariado ruso se resistía a entrar en los teatros porque los consideraba ajenos; por esa razón, durante un tiempo se realizaron las representaciones al aire libre para que el público asistiera. (Prieto López 2017)

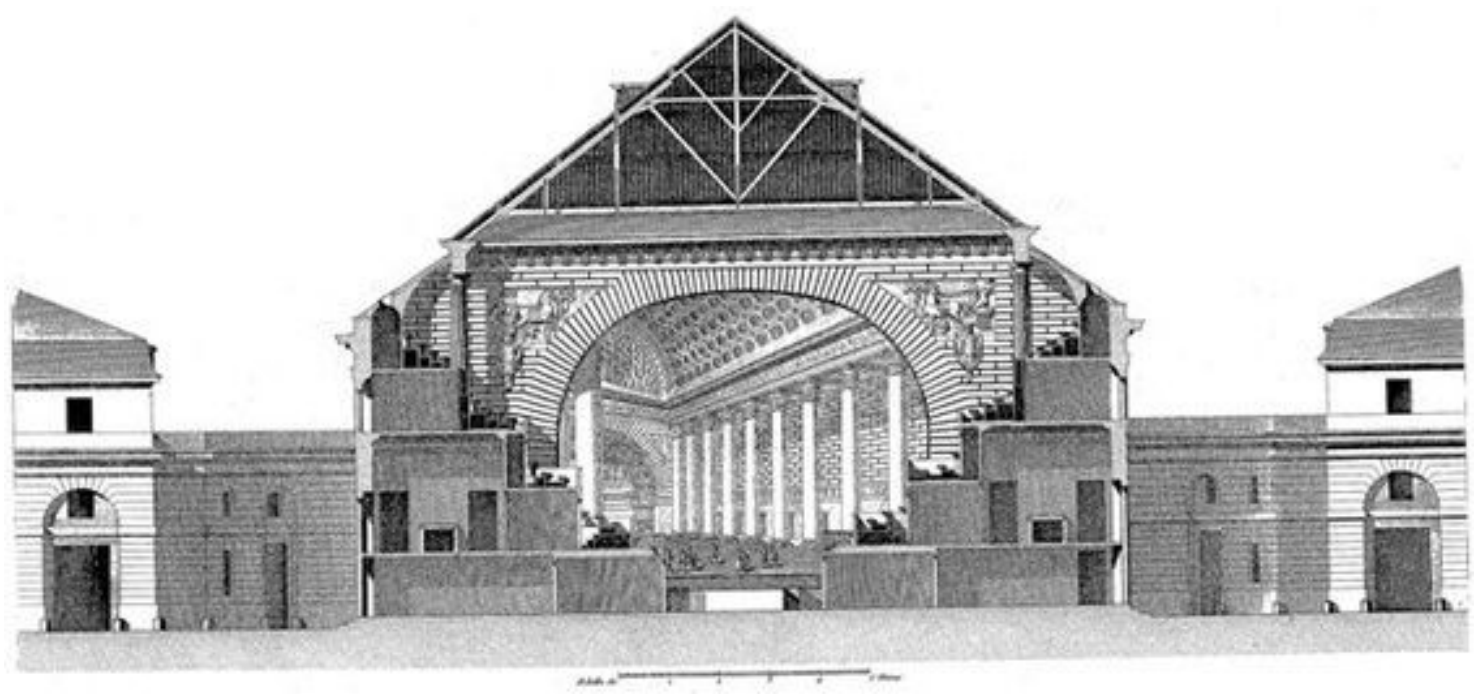

Fig. 1. Teatro de Besançon, Claude-Nicolas Ledoux, sección transversal de su primera propuesta. Fuente: Vidler 1994, p. 92-93.

En cuanto a los antecedentes dentro de la Iglesia, fue en el segundo tercio del siglo XIX cuando se hicieron oír los críticos con la liturgia católica. Se trataba de los trabajos previos al Movimiento Litúrgico ${ }^{3}$. En cierta medida, coincidían con los críticos de las salas de teatro a la italiana en que les parecía que se había desvirtuado la verdadera naturaleza de ambos, y veían afectados de los mismos males a sus respectivos espacios de celebración.

Ya a inicios del siglo XX, en las iglesias y en las salas de teatro a la italiana se iniciaron en paralelo los procesos de cambio, que implicaron la desfuncionalización de los espacios, con su consiguiente abandono o su reprogramación. En muchos casos se desplegaron una serie de estrategias relacionadas con el concepto de profanación, según el significado que le otorga Giorgio Agamben a este término, con claras implicaciones políticas.

Según Agamben, la profanación viene a ser lo opuesto a la sacralización, entendida esta como la sustracción de algo que pertenece a la esfera de los humanos para su separación en esferas no accesibles: "Profanar significa abrir la posibilidad de una forma especial de negligencia, que ignora la separación o, sobre todo, hace de ella un uso particular.” (Agamben 2006, p. 99). La sucesión de cambios en los espacios de representación teatral y de la liturgia católica han supuesto una especie de negligencia profanadora, que ha tendido

\footnotetext{
${ }^{3}$ El Movimiento Litúrgico fue una corriente renovadora que trabajó con el objetivo de restaurar una liturgia que se consideraba desviada de su verdadera naturaleza, por lo que se basaron en investigaciones históricas. Inició su actividad en el segundo tercio del siglo XIX y terminó en el Concilio Vaticano II, que supuso su culminación. Produjo la reestructuración de la disposición interior de los templos existentes y la aparición de nuevos tipos, todo ello orientado a posibilitar el desarrollo de la liturgia renovada. (Plazaola 1965, p. 75-81)
} 
a eliminar la separación de los espacios a los participantes o "a hacer de ella un uso particular”. Todo ello ha ido de la mano de una mayor integración de esos participantes en las celebraciones, a los que se les empezó a proponer una implicación más activa. En ese sentido, es significativa la progresiva apertura de partes del templo a los fieles - a los que se recordó su propio sacerdocio para que ampliaran su campo de acción-mediante la eliminación de elementos físicos como las rejas del presbiterio o la reducción del desnivel que tenía con la nave. En los teatros, la desaparición de los palcos o la integración cada vez mayor del escenario en la sala son ejemplos de ese mismo proceso de profanación.

Lo que tuvieron en común las situaciones que se plantearon en los ámbitos del teatro y de la liturgia católica, incluyendo sus espacios asociados, parece haber llevado a que se miraran mutuamente, como si se buscaran a sí mismos en las propiedades más genuinas del otro. En los dos ámbitos existía la conciencia de que habían perdido, a lo largo de muchos siglos de evolución, aspectos fundamentales de su verdadera naturaleza. En esta idea coincidían también con el conjunto de las artes de las vanguardias históricas, que reaccionaron contra una tradición que consideraban falsa y contra el museo como su espacio característico. Así, en el caso de la Iglesia, y como resultado del concienzudo trabajo de investigación sobre la liturgia de la misa católica iniciado décadas antes por el Movimiento Litúrgico, en los años 20 se propuso una reestructuración de las misas en torno a la escenificación de la última cena ${ }^{4}$.

La misa católica se organizaría en adelante como una actualización de aquel banquete, que, aunque iba más allá de una representación, contaba con un nuevo contenido teatral, basado en la recuperación de la misa primitiva. Según esa escenificación, lo ideal sería que los asistentes se colocaran alrededor del altar como si estuvieran sentados a la mesa en la última cena, reproduciendo en la liturgia de la misa lo ocurrido en aquel banquete, parecido a como lo habrían hecho los primeros cristianos en las domus ecclesiae. Sin embargo, el número de asistentes poco tenía que ver con aquellas reuniones de carácter doméstico, lo que obligó a repensar el trazado de nuevas iglesias para intentar adaptar ese modelo de celebración a un espacio mayor, con más fieles participando (Fig. 2). Este nuevo planteamiento llevó a que se prodigaran los esquemas de organización centralizada frente a la procesional de las basílicas tradicionales, aunque estas siguieron y aún siguen en nuestros días manteniendo su vigencia. (Capitel 1998, p. 69) Los esquemas centralizados quedaron así asociados a la renovación de la liturgia desde los años 20, aunque de manera oficial se asumiera su idoneidad solo - y tácitamente- desde el Concilio Vaticano II.

\footnotetext{
${ }^{4}$ THE NATURE OF THE MASS RITE Principally, then, the Mass is a banquet, a banquet indeed from which flow life eternal, union with Christ, and resurrection. Furthermore, the paschal lamb, the type of the Mass, was a memorial banquet; So too the Mass is a memorial banquet: "Do this for a commemoration of me." And the Mass is a sacrificial banquet, for in it we partake of the flesh of Christ, which He offered in sacrifice, and of His blood, which He shed for us. From Christ, therefore, we learn that the Mass is a banquet of remembrance and of sacrifice. (Parsch 1940, p. 5)
} 

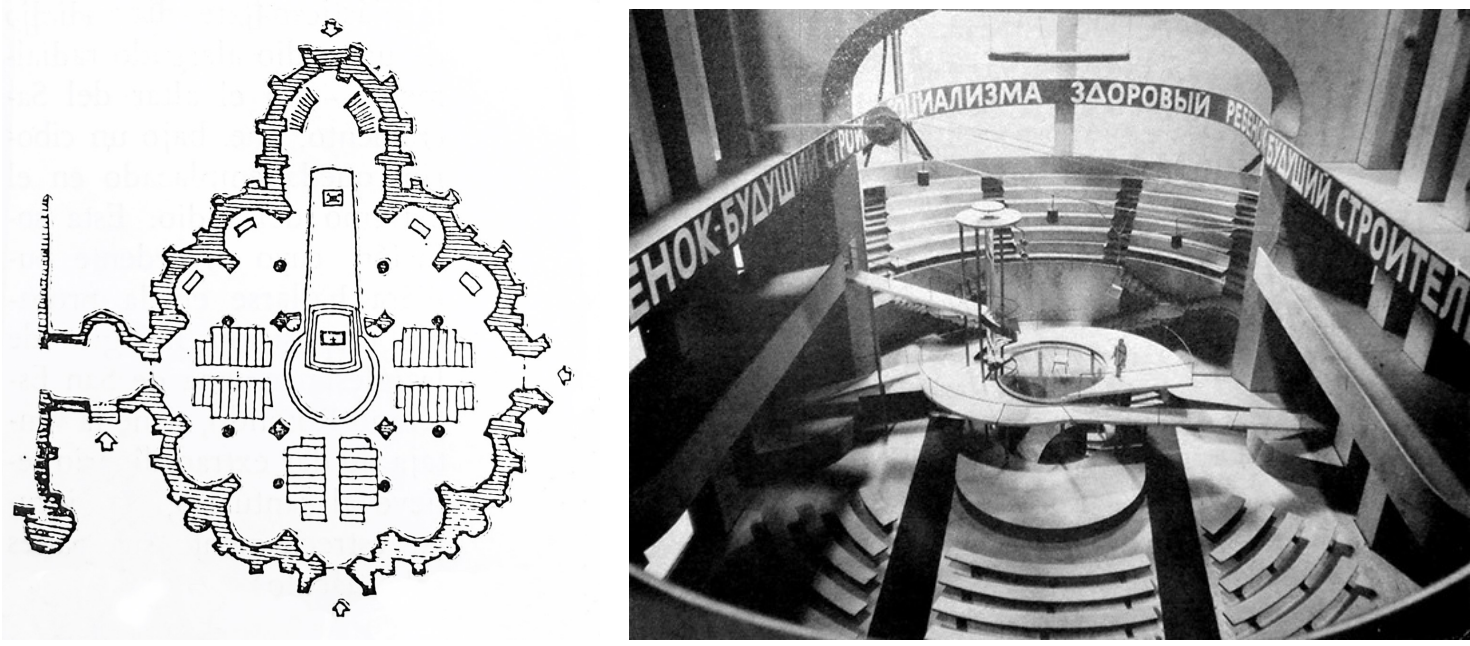

IZQ. Fig. 2. Reorganización interior para la nueva liturgia de la Iglesia de Ntra. Sra. de Tréveris, en el conjunto de la catedral. EI altar de la eucaristía avanza hacia el centro del espacio mientras que el tabernáculo queda en el antiguo presbiterio, ambos unidos por una zona elevada a modo de pasarela. Los fieles rodean el altar como sentados a la mesa de la última cena. Fuente: Plazaola 1965, p. 245

DER. Fig. 3. Teatro revolucionario ruso. El Lissitzky, maqueta para el montaje de ¡Quiero un niño!, 1928-1929. El área escénica conecta distintas zonas de público y actores desde el sótano a la galería superior con recorridos espirales o helicoidales mediante rampas y escaleras, que se prolongaban hasta la vía pública. Fuente: Prieto López, 2017.

En el mismo periodo de entreguerras, el teatro de vanguardia de Antonin Artaud - y más adelante, en la segunda vanguardia, el teatro sagrado de Peter Brook o el de Jerzy Grotowski entre otros - trató de asimilar los rituales religiosos propios de prácticas teatrales primitivas o exóticas (Innes 1992, p. 25). Artaud incluso propuso en sus manifiestos del Teatro de la Crueldad abandonar los teatros para ocupar naves agrícolas en desuso acondicionadas según "algunas iglesias". ${ }^{5}$ Proponía esquemas organizativos en que la escena quedara integrada en la sala, con el público rodeando la acción y también envuelto en ella.

\footnotetext{
${ }^{5}$ Descripción del espacio escénico propuesto para El teatro de la crueldad, Primer manifiesto, incluído en El teatro y su doble de Antonin Artaud: "LA ESCENA. LA SALA. Suprimimos la escena y la sala y las reemplazamos por un lugar único, sin tabiques ni obstáculos de ninguna clase, y que será el teatro mismo de la acción. Se restablecerá una comunicación directa entre el espectador y el espectáculo, entre el actor y el espectador, ya que el espectador, situado en el centro mismo de la acción, se verá rodeado y atravesado por ella. Ese envolvimiento tiene su origen en la configuración misma de la sala. De modo que, abandonando las salas de teatro actuales, tomaremos un cobertizo o una granja cualesquiera, que modificaremos según los procedimientos que han culminado en la arquitectura de ciertas iglesias, de ciertos lugares sagrados y de ciertos templos del Tibet Superior. En el interior de esa construcción prevalecerán ciertas proporciones de altura y profundidad. Cerrarán la sala cuatro muros sin ningún adorno, y el público estará sentado en medio de la sala, abajo, en sillas móviles, que le permitirán seguir el espectáculo que se ofrezca a su alrededor. En efecto, la ausencia de escena en el sentido ordinario de la palabra invitará a la acción a desplegarse en los cuatro ángulos de la sala. Se reservarán ciertos lugares para los actores y la acción en los cuatro puntos cardinales de la sala. Las escenas se interpretarán ante muros encalados, que absorberán la luz. Además, en lo alto unas galerías seguirán el contorno de la sala, como en ciertos cuadros primitivos. Tales galerías permitirán que los actores, cada vez que la acción lo requiera, se persigan de un punto a otro de la sala, y que la acción se despliegue en todos los niveles y en todos los sentidos de la perspectiva, en altura y en profundidad. (...) Sin embargo, ha de reservarse un emplazamiento central que sin servir propiamente de escena, permita que el grueso de la acción se concentre e intensifique cada vez que sea necesario."
}

(Artaud 2015, p. 127) 


\section{Implicaciones políticas: el movimiento de las funciones y de los cuerpos}

En las profanaciones y desplazamientos del teatro y la liturgia se deja ver la influencia de los ideales revolucionarios de la Ilustración, que llevaron a replantearse los espacios de la vida pública e institucional, con la aparición de nuevos tipos edificatorios y la revisión de los existentes. Immanuel Kant identificó Ilustración con emancipación (Kant 2009, p. 249), entendiendo esta como una liberación de cada individuo a través de su propio pensamiento, del uso autónomo de la razón. Aparte de las consecuencias que pudiera tener para las creencias religiosas, de las que el mismo Kant propone emanciparse, desde la Ilustración y la Revolución Francesa el término emancipación ha sido fundamental para dar forma a la sociedad moderna, y en su sentido político expresa el ideal de acabar con la dominación de unas personas sobre otras, de unas clases dominantes sobre otras oprimidas.

El concepto de alienación va acompañando y dando forma al de emancipación a lo largo de la modernidad. Para un buen número de autores, la alienación se relaciona en esa etapa de dos siglos con la creciente separación de las personas entre sí, de estas con los medios de producción que la industrialización les había sustraído y, en general, con unas vidas compuestas de partes separadas, desprovistas así de todo aquello que en el pasado les había proporcionado arraigo y autenticidad a su existencia ${ }^{6}$. El concepto de alienación se convertiría en argumento recurrente de muy diversos movimientos artísticos —unir el arte con la vida- y políticos revolucionarios. Todo ello tendrá su reflejo en los espacios de esa nueva sociedad, y las iglesias y los teatros no serán ajenos a esos cambios, que cuestionaban las distintas delimitaciones de lo que podía ser la vida de cada persona en una misma sociedad.

Guy Debord resume en la primera página de su libro La sociedad del espectáculo-escrito al final de la modernidad- ese proceso moderno de separación entre lo real y la vida las personas al afirmar que "Todo lo directamente experimentado se ha convertido en una representación”. (Debord 2009, p. 37) Podemos así pensar que, si en la liturgia se daba lo directamente experimentado - sobre todo por su conexión con lo trascendente-, era seguro que se estaría convirtiendo de algún modo en una representación para adaptarse a la modernidad - o simplemente por estar en ella-. Por otro lado, el teatro, que ya se había reducido antes a una simple representación - según había denunciado

\footnotetext{
${ }^{6}$ Es significativo en ese sentido que el primer capítulo del libro La sociedad del espectáculo de Guy Debord —escrito al final de la modernidad, revisándola a través de su concepto de espectáculo, que a su vez engloba otros como los de separación y alienación- se titule La separación perfecta. Ese primer capítulo comienza - y con él el libro - con una cita de Feuerbach, L. en la que ya denunciaba, en 1848: "Nuestra época, sin duda alguna, prefiere la imagen a la cosa, la copia al original, la representación a la realidad, la apariencia al ser... Para ella, lo único sagrado es la ilusión, mientras que lo profano es la verdad. Es más, lo sagrado se engrandece a sus ojos a medida que disminuye la verdad y aumenta la ilusión, tanto que el colmo de la ilusión es para ella el colmo de lo sagrado." (Debord 2009, p. 37) Y en otro apartado añade Debord: "El espectáculo, entendido en su totalidad, es al mismo tiempo el resultado y el proyecto del modo de producción existente. No es un suplemento del mundo real, una decoración sobreañadida. Es el núcleo del irrealismo de la sociedad real. Bajo todas sus formas particulares -información o propaganda, publicidad o consumo directo de diversiones-, el espectáculo constituye el modelo actual de vida socialmente dominante." (Debord 2009, p.39)
} 
Artaud ${ }^{7}$ entre otros muchos autores de la renovación del teatro a lo largo del S. XX-para dejar de serlo, debía convertirse en algo directamente experimentado, de ahí que una salida fuera su ritualización y sacralización.

Lo político, entendido como lo que define ese margen de lo posible en la vida de las personas, de manera que constituye el sistema que dicta las relaciones económicas con que se regulan las sociedades y que establece lo que se puede y lo que no se puede ser o hacer en ellas, se estaría poniendo en juego en las operaciones espaciales de profanación referidas, que precisamente actúan en la separación. Como se trata de una relación de interdependencia o de influencia mutua entre lo político y lo espacial, dichas operaciones por un lado serían consecuencia de cambios en lo político y, por otro, serían prácticas políticas, por lo que tendrían cierta capacidad de intervenir en el sistema de producción y de regulaciones, pudiendo alterar — ensanchar en este caso- los límites de lo que puede ser la vida de cada persona.

Como ocurrió en las vanguardias del Dadá y del Surrealismo, en los espacios de representación teatral y de culto católico desde inicios del siglo XX se dieron juegos con la función no exentos de implicaciones políticas. Ya en el periodo de entreguerras, en los primeros textos que relacionan arte de las vanguardias y política, donde Walter Benjamin acuña los conceptos de estetización de la política y de politización del arte para describir unos fenómenos que observaba en el arte de esos años y su relación con los movimientos políticos, incluye ejemplos de las artes escénicas de la época. Entendía que había un arte que servía para emancipar y otro para someter, en función de su relación con la política, que hacía corresponder respectivamente con el Comunismo y el Fascismo. Citaba el teatro revolucionario ruso y los eventos multitudinarios del nazismo para ilustrarlo. (Benjamin 2003, p. 96-99)

Los cambios propuestos tanto en la liturgia como en el espacio de las iglesias tienen que ver con una tendencia hacia la liberación de los movimientos de los cuerpos en el espacio, quizá por las posibilidades que ofrece de hacer un uso distinto de la separación. Lo mismo parece haber ocurrido con el teatro (Fig. 2, 3, 4 y 5). Lo que empezó siendo una liberación de la visión - como en el teatro de Besançon-, que podía barrer todo el espacio de manera que cada uno de los actores y del público podía ver todo y ser visto (Ramírez 2003, p. 86), terminó siendo una liberación de los cuerpos para ocupar ese espacio y apropiárselo con su movimiento. De hecho, la exaltación del movimiento como recuperación de la autenticidad perdida se aplicaba a todos los asistentes a las misas, fuera cual fuera su función. Esta situación se desarrolló principalmente desde los años previos al

\footnotetext{
7 "Si la multitud ha perdido la costumbre de ir al teatro, si todos hemos llegado a considerar el teatro un arte inferior, un medio de distracción vulgar, y lo utilizamos como exutorio de nuestros peores instintos es porque nos dijeron demasiadas veces que era teatro, o sea, engaño o ilusión; porque durante cuatrocientos años, es decir desde el Renacimiento, se nos ha habituado a un teatro meramente descriptivo y narrativo, de historias psicológicas; porque se las ingeniaron para hacer vivir en escena seres plausibles pero apartados —el espectáculo por un lado y el público por otro-y no se mostró a la multitud sino su propia imagen." (Artaud 2015, p. 102)
} 
Concilio Vaticano II. Como ejemplo, se instauró la llamada comunión procesional frente a la estática en las barandillas-reclinatorio que delimitaban el presbiterio, en las que permanecían arrodillados e inmóviles los fieles mientras esperaban a que el sacerdote les diera la comunión. Asimismo, los oficiantes de la ceremonia comenzaron a disponer de más espacio al tiempo que los acólitos y los feligreses se desplazaban y apropiaban dinámicamente del mismo en función de los tiempos de la liturgia (Fig. 5); tal y como recogió de manera clara y humorística Federico Fellini en una secuencia de su película Roma, de 1972. (Fig. 4)
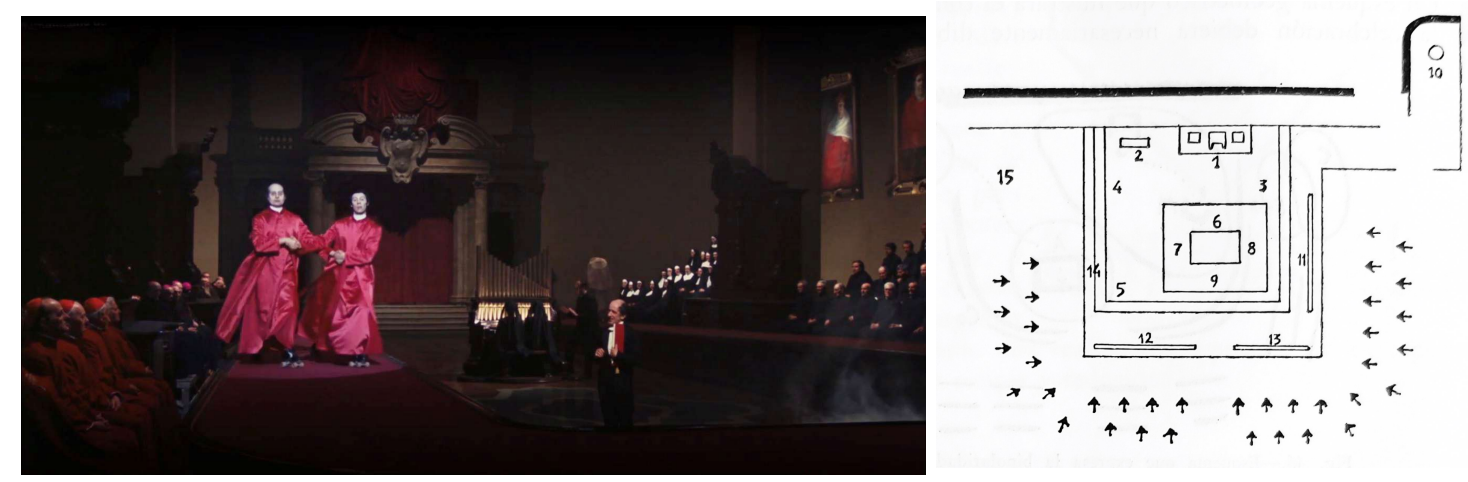

IZQ. Fig. 4. Fotograma de la secuencia del desfile de moda sacra del film Roma, de Federico Fellini, 1972. Fuente: Filmin

DER. Fig. 5. Ejemplo de un presbiterio con repartición dinámica para la liturgia renovada, en la que se contaba con la intervención de los fieles: 1-5. área de la liturgia de la Palabra. 6. Lugar del celebrante. 7-9. Lugar de los ministroc. 10. Área del tabernáculo. 11-13. Comulgatorio. 14. Grada para la comunión de acólitos y cantores. 15. Coro. Fuente: Plazaola 1965, p. 187

El movimiento incluso llegó a incorporarse como una cualidad espacial más en las iglesias. Es el caso del del 'espacio dinámico' de Miguel Fisac, que empleó por primera vez en la parroquia de Nuestra Señora de la Coronación de Vitoria (1957-60). Un muro dinámico, caracterizado por un trazado curvo, sirve para orientar la vista y acompañar el movimiento de los fieles hacia el altar. (García-Asenjo Llana 2016, p. 69-70)

Por tanto, movimiento de los cuerpos, participación y un mayor dominio del espacio por parte de los fieles, están implícitos en la renovación de la liturgia. Es algo parecido a lo que ocurrió con el papel del público en la renovación del teatro del siglo XX, donde participaban en la representación actuando entre los actores en una nueva disposición espacial más integrada; lo mismo pasó con el espectador del arte de vanguardia, donde se empezó a contar con su intervención activa, con una participación que lo convertiría también en autor.

En las décadas de los 60 y 70, durante la etapa de la llamada segunda vanguardia, se da un paso más en la consideración de los participantes en esos tres ámbitos. En cuanto a los fieles porque se considera que la misa sin su participación individual no es posible, instituyéndose, por ejemplo, la posición del sacerdote de cara a los fieles y hablando en su lengua local, además de establecerse un diálogo en el que entre todos completaran el texto de la liturgia. En cuanto al teatro, Cornago Bernal afirma que los autores de esa neovanguardia "En los años sesenta desarrollaron otra concepción del público, alejada ya del 
concepto de masa indiferenciada, que vendría a satisfacerse bajo los modelos del teatro como ritual para iniciados, ceremonia mística o juego popular, en los que, sin perder de vista el sentido colectivo de la fiesta, el espectador era invitado a una participación directa y diferenciada." (Cornago Bernal 2000, p. 22-23)

Las propuestas de participación de público y asistentes contienen elementos lúdicos que hunden sus raíces en los primitivos rituales que dieron origen al teatro y a las ceremonias religiosas, y de los que aún quedan huellas en diversas situaciones de la vida cotidiana. Giorgio Agamben considera al juego como la herramienta más eficaz de profanación, porque según afirma, desactiva el uso que les asignan las esferas de la separación al objeto (la economía, el derecho y la política) y activa nuevos usos. (Agamben 2005, p. 113) Entre dichos elementos lúdicos y el movimiento de los cuerpos en el espacio se produce una sinergia integradora, parecida a un antiguo elemento motor que ayudara a colocarse a cada uno en el rincón que le corresponde en cada momento. Para ello es necesario hacer un uso algo distinto del espacio, con una libertad que parece haberse reivindicado a lo largo de la modernidad bajo el paraguas genérico de la emancipación.

En cuanto a esa función integradora del juego, se pueden detectar otros comportamientos liberados de las reglas espaciales a partir de un momento dentro de la iglesia, en el que se plantea una nueva forma de jugar la religiosidad individualmente. Desde el Concilio Vaticano II fue comúnmente aceptado que cada cristiano debía unir religión católica y vida cotidiana, algo que recuerda al ideal de las vanguardias históricas de unir el arte con la vida, que sigue hoy en día tan vigente como entonces. Esa nueva actitud propuesta para los cristianos respecto de su vida religiosa viene a significar que no se es más cristiano cuando se está dentro del espacio de la iglesia que en cualquier momento o espacio de la vida diaria, de manera que el templo no será el único lugar para el encuentro con Dios como se entendió durante siglos. Esta idea supone una liberación del cuerpo con respecto al espacio, que permite un desplazamiento de lo sagrado - de la función sacra- allí donde se encuentre cada persona, propiciando una relación menos rígida y más activa y privada con la divinidad.

El vínculo tradicional entre la liturgia y el espacio sagrado de las iglesias también se debilita en esa misma época. Se considera desde entonces que lo sustancial es la asamblea y no el edificio; así, se recuerdan las palabras de Jesucristo: "donde estuvieren dos o tres reunidos en mi nombre, allí estoy yo en medio de ellos.” Mt 18.20. (Plazaola 1965, p. 239), de manera que la liturgia se independizó como programa -aunque fuera parcialmentede los edificios que durante tantos siglos los habían alojado. La pérdida de la rigidez de ese vínculo espacial se justificó entonces como algo absolutamente ineludible, como una recuperación necesaria de la propia esencia de la liturgia y de la Iglesia. Es más, según sostenían los liturgistas, el verdadero templo es el cuerpo de Cristo, que es donde habitó Dios en la tierra. (Fernández Cobián 2005, p. 202) Podemos ver aquí otro desplazamiento de la función que quedó instituido con el fin de aportar una mayor autenticidad, valiéndose de la coartada de la vuelta al origen. 


\section{Interior profanado}

La modernidad, surgida del impacto que supuso la Ilustración, fue una sucesión de profundos cambios sociales que iban alejando a la población de la fe cristiana y retiraban la influencia de la Iglesia de ámbitos tradicionalmente suyos. Para frenar la progresiva profanación de lo sagrado, inicialmente se dieron reacciones en contra, tal como recogió el Concilio Vaticano I, a mediados del siglo XIX (Laboa 2002, p. 105-106). Sin embargo, la mayor parte de los cambios y asimilaciones de elementos externos vino de la mano del Movimiento Litúrgico, que pertenecía a la propia Iglesia y que comenzó a dar sus primeros pasos en esa época.

Con la renovación de la liturgia, se incorporaron elementos profanos interior de las iglesias procedentes del ámbito teatral. La redefinición de la misa católica con la escenificación de la última cena coloca el altar en una posición centrada y cerca de los fieles sin apenas distancia, y sin elementos físicos o desniveles que dificultaran el acceso o el movimiento. (Plazaola 1965, p. 81) Esta disposición es parecida a diversas propuestas del teatro revolucionario soviético tendentes a evitar la separación entre escenario y patio de butacas, tales como los aparatos teatrales que conectaban la escena con la zona de público para facilitar su participación activa en las representaciones. (Fig. 2) También es análoga a las propuestas de Artaud para su Teatro de la Crueldad y para el posterior teatro muy influido por él, sobre todo el llamado ritual o sagrado.

Muchos de los aspectos espaciales descritos habían sido introducidos a mediados del siglo XIX en los pequeños locales donde se representaba el music hall y el teatro de variedades en algunas ciudades europeas, que constituían una de las primeras manifestaciones de la cultura de masas - lo que quizá explique algunos paralelismos- y que serían un referente clave para el entonces futuro teatro de vanguardia. Es decir, existía un amplio sector de población que, coincidiendo con los inicios del Movimiento Litúrgico, había adquirido cierta costumbre de reunirse en locales de tamaño mediano o pequeño, de manera más bien informal y sin una separación demasiado marcada entre escenario y público. Se ofrecía a veces espectáculo y cena, con lo que sintonizaba aún más con la renovación de la liturgia. El desfile de moda sacra de la película Roma de Federico Fellini (Fig. 4) recoge de forma muy clara algunos de esos aspectos profanos: el dispositivo escénico de la pasarela, la disposición del clero asistente o el despliegue de recursos escenográficos llenos de dinamismo son los más llamativos. El público, entre tanto, tomaba un aperitivo. 


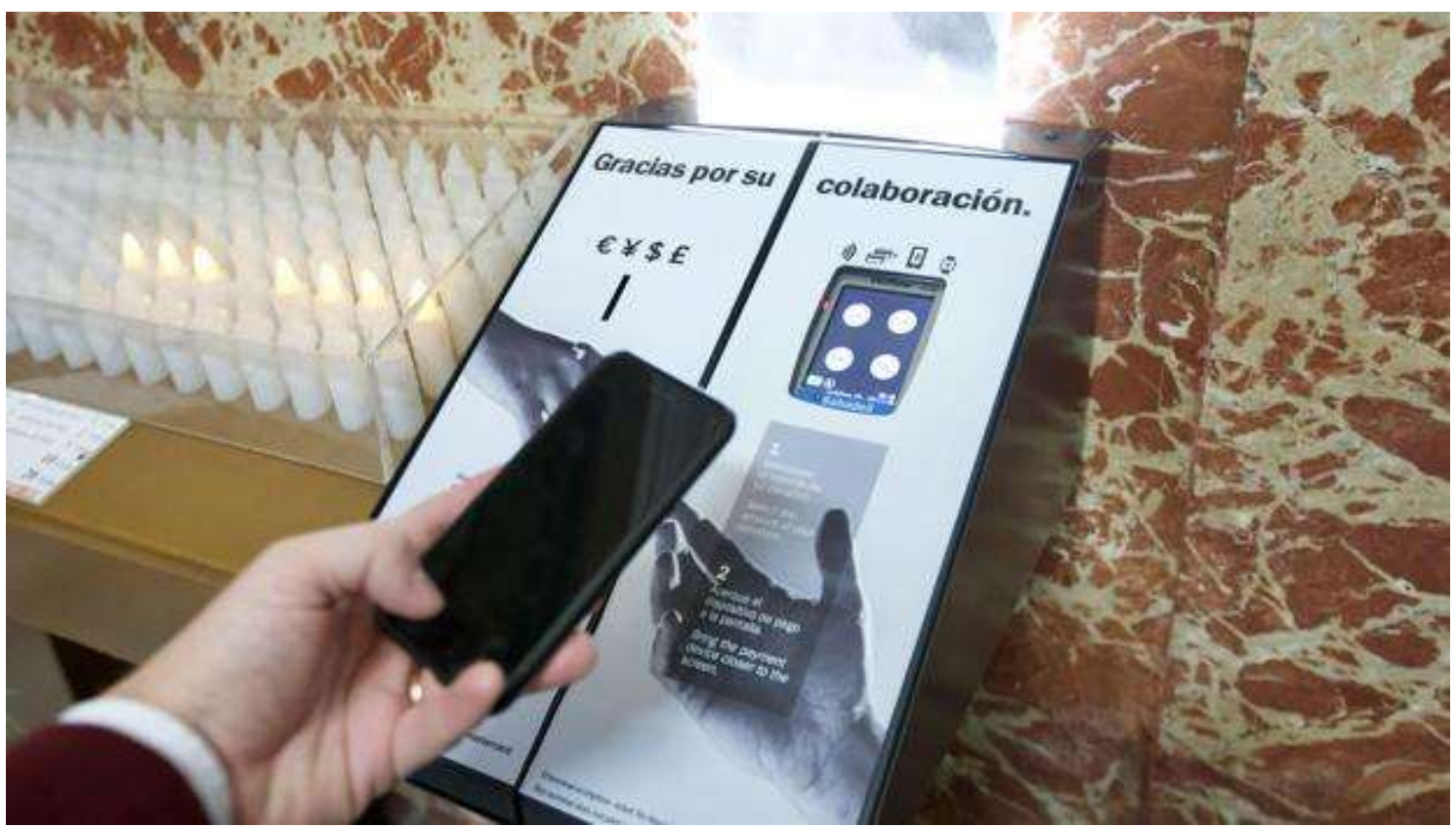

Fig. 6. Terminal de pago de donativos mediante teléfono móvil instalado en la Basílica de la Virgen de los Desamparados en Valencia - Fuente: edición digital del periódico ABC: https://www.abc.es/espana/comunidad-valenciana/abci-cepillo-iglesiasconecta-movil-y-tarjeta-201811221750_noticia.html

Ya a mediados del siglo XX, el esfuerzo por adaptarse al mundo contemporáneo implicaba seguir manejando la separación entre lo sagrado y lo profano, teniendo más en cuenta cada vez lo humano frente a lo divino. El esquema preparatorio al Concilio Vaticano II —que fue ampliamente aplaudido por los obispos presentes- ya contenía propuestas que abrían la puerta a aspectos extraños a la tradición de la liturgia, como hacer la misa más corta, eliminando lo "repetitivo y complicado en exceso" porque se correspondía mejor con el sentir del hombre moderno. (Wiltgen 1999, p. 32)

El Concilio Vaticano II finalmente supuso la incorporación de más elementos profanos a su liturgia, sobre todo en países alejados de Europa. En esos territorios, los misioneros católicos, pese a la oposición del sector ultraconservador, consiguieron que se incluyeran aspectos de las culturas locales como la lengua vernácula o las tradiciones culturales o religiosas, externas a los límites establecidos para lo sacro en la Iglesia Católica hasta ese momento. (Wiltgen 1999, p. 22)

Paralelamente, en esos mismos años, el teatro daba un paso más en la asimilación de lo sagrado; así, según sostiene Cornago Bernal "El ritual constituyó uno de los modelos más eficaces para la renovación de los lenguajes teatrales en la vanguardia internacional. Las relaciones antropológicas entre rito y teatro se erigieron como un importante parámetro que canalizó algunas de las propuestas de las vanguardias iniciales y que, en los años sesenta, volvió a surgir como uno de los núcleos fundamentales en torno al cual se desarrollaron diferentes ramificaciones, no siempre coincidentes, configurando un amplio, rico e incluso contradictorio movimiento teatral." (Cornago Bernal 2000, p. 35)

Un ejemplo de espacio asociado a esas transformaciones del teatro es la propuesta de sala escénica para el Teatro Oficina, terminado en 1994, de Lina Bo Bardi y Edson Elito. (Fig. 8) 
Se trata de un espacio teatral que los autores cargaron de elementos sagrados probablemente porque se inspiraron para el proyecto en los orígenes del teatro de vanguardia $^{88}$. De hecho, la sala materializa los preceptos descritos en el Manifiesto del Teatro de la Crueldad, de Antonin Artaud, como son la disolución de la escena en la sala o la colocación del público rodeando a la acción y participando de ella, las pasarelas elevadas o los elementos sagrados como la pila y la fuente o la idea de que es un "terreiro", peculiar espacio sacro-profano de la tradición local.

No obstante, conviene aclarar que constituye un ejemplo que ilustra a la vez la sacralización y la profanación del espacio teatral. Se sacraliza el espacio con la inclusión de los elementos sagrados mencionados, con el carácter procesional del espacio o con el uso de la luz natural que entra desde cierta altura a través de la ventana-vitral. Y se profana en cuanto a la eliminación de las separaciones o al juego creativo con ellas. Así, la misma ventana que aporta una atmósfera sagrada permite, con su transparencia y la altura de su alfeizar, al exterior entrar en la sala, profanándola al eliminar su separación tradicional con el mundo. Hay otros elementos que profanan el interior como un techo corredizo o el suelo de tierra y las plantas que crecen en ella; pero, sobre todo, es la eliminación de las separaciones entre público y actores lo que supone el núcleo de la profanación.
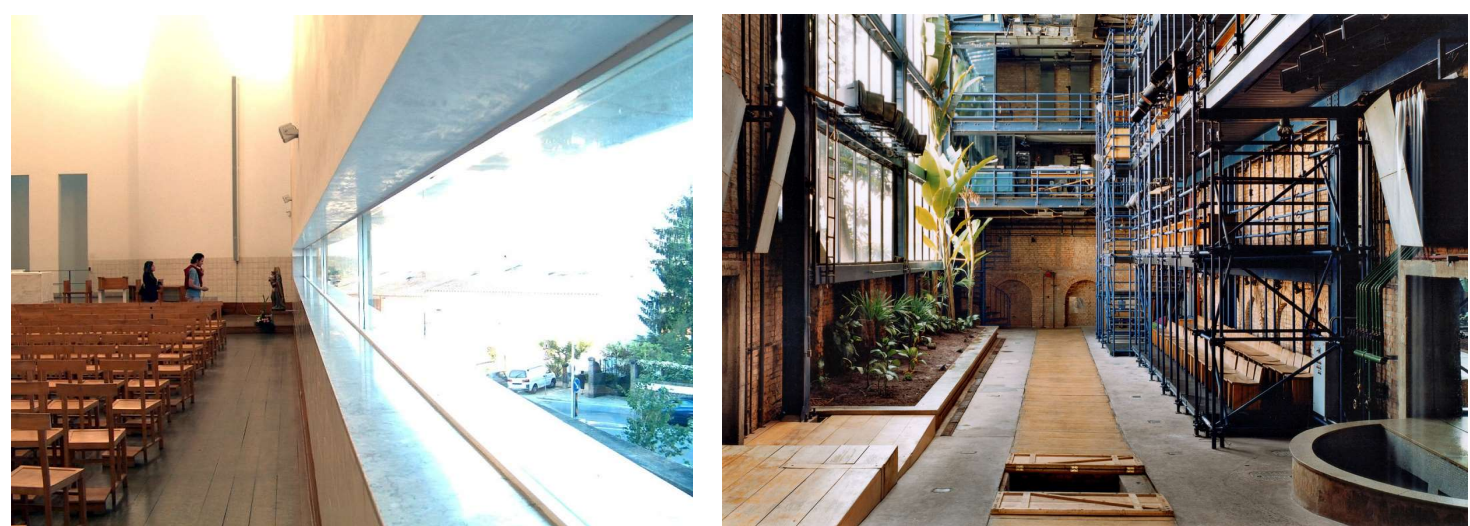

IZQ. Fig. 7. Álvaro Siza, centro parroquial en Marco de Canavezes (1990-1997). Ventana horizontal a la altura de los ojos que hace visible el exterior desde la iglesia durante la liturgia. Fuente: Fernández Cobián 2016

DER. Fig. 8. Lina Bo Bardi y Edson Elito, Teatro Oficina (1980-1994). Ejemplo construido de sala teatral sacralizada que contiene los preceptos descritos en el Manifiesto del Teatro de la Crueldad, de Antonin Artaud. Es interesante el doble efecto espacial del ventanal, en cuanto a que sacraliza y profana el espacio a partes iguales: por un lado, es un vitral que deja entrar la luz natural desde lo alto como si de una iglesia se tratara; y por otro, por su completa transparencia y por la posible colocación de los participantes en altura, deja entrar el exterior a la sala, profanándola. Fuente: Plataforma de Arquitectura: https://www.plataformaarquitectura.cl/cl/898003/clasicos-de-arquitectura-teatro-oficina-lina-bo-bardi-and-edsonelito/599d6e3db22e38f089000074-ad-classics-teatro-oficina-lina-bo-bardi-and-edson-elito-photo?next_project=no

\footnotetext{
${ }^{8}$ La reconstrucción del teatro oficina de Lina Bo bardi y Edson Elito estuvo marcada por la coincidencia temporal de la etapa de redacción del proyecto con de la representación de la obra Ubú Rey, de Alfred Jarry -un referente para el teatro de vanguardia y para las vanguardias artísticas del Dadá y Surrealismo- con escenografía de Lina Bo Bardi. Producía la obra de Jarry la compañía El Ornitorrinco, que ensayaba en el Teatro Oficina. La obra se representó cuando todavía los arquitectos estaban en fase de ideación del proyecto de transformación completa del teatro. Esta circunstancia expuso a Lina Bo Bardi a las ideas de participación del público, flexibilidad e improvisación, y pudo incorporarlas al proyecto por la fase en que se encontraba. (de A. Lima 2013, p. 181-182)
} 
En cuanto a las iglesias, tres años después de la terminación del Teatro Oficina, encontramos un ejemplo que opera de forma parecida con la separación, algo muy novedoso en el espacio sacro. Así, se materializó la entrada literal — no ya de elementos más o menos metabolizados-del mundo exterior profano en el espacio de la liturgia. En el centro parroquial de Marco de Canavezes, Álvaro Siza, en los años 90 ya hizo una iglesia adaptada a los tiempos sin renunciar a una lograda atmósfera de espacio sagrado. Para conseguir su propósito, utilizó como base la tradición de los templos católicos con su fuerte carga simbólica. A la vez, hizo algo totalmente insólito para esa tradición: colocó una ventana horizontal a la altura de los ojos que hace visible el exterior desde la iglesia. (Fig. 7) Con ese gesto no hizo más que reconocer la realidad de que se había diluido ya la antigua separación con el mundo. Si el exterior profano estaba en la iglesia y se confundía con lo sagrado, de nada serviría impedir la vista a través de las ventanas para mantener la separación: ya no tenía sentido limitar los huecos de las iglesias a vidrieras altas o claristorios; de ahí que esa extraña ventana haya sido ampliamente aceptada.

Siza parece haberse percatado entonces de que las iglesias en los 90 difícilmente podían ser ese otro espacio distinto y aislado del mundo que habían llegado a ser justo antes de la modernidad: un espacio salvífico, casi como la antesala del cielo. Hoy en día no es solo más difícil, sino que ya es del todo imposible: cada persona que entra en la iglesia lleva el mundo exterior en su bolsillo en forma de dispositivo móvil de telefonía, conectado con cualquier contenido, con micrófonos y cámaras que espían y con alertas que reclaman la atención de quien los porta. Incluso en el cepillo de las iglesias se pueden dejar donativos con pagos desde el teléfono móvil, que encenderán unas velas que hace décadas que no conocen la cera. (Fig. 6)

La iglesia de Siza viene a ilustrar también la histórica relación entre la Iglesia Católica y las artes, que se caracterizó a lo largo de dos milenios por una influencia mutua, en la que el arte se ponía al servicio de la religión, ayudando a la actualización de las costumbres y normas de la iglesia mediante propuestas tendentes a ampliar los recursos materiales disponibles. Se limitaba, en definitiva, a producir más desarrollados dispositivos espaciales o un mejorado equipamiento para la liturgia. (Plazaola 1965, p. 66) Desde mediados del siglo XIX, cuando se emprendió la renovación de la liturgia, se observa una influencia del arte sobre la Iglesia que va más allá de esa vocación de servicio: se convirtió no solo en una puerta de entrada del mundo exterior profano al interior de la iglesia —como en Marco de Canavezes-, sino que, a la vez, sirvió para esparcir fuera de ella contenidos sagrados mediante determinadas operaciones artísticas. Los recursos desplegados por el dadaísmo, sobre todo mediante el ready-made-en prácticas equivalentes en el espacio arquitectónico-, de cambios de contexto, significado y función constituyen el núcleo fundamental de dichas operaciones artísticas.

Un ejemplo que lo ilustra muy claramente es el altar provisional para celebración de la eucaristía al aire libre Dornenkrone (corona de espinas), de Rudolf Schwarz y el escultor Theo Hiermann, 1956, Colonia (Fig. 9). El empleo de la técnica del ready-made es evidente en la recontextualización y cambio de significado de las grúas y la corona de espinas, esta con un cambio de escala propio del Pop Art de la época. 


\section{Exterior sacralizado}

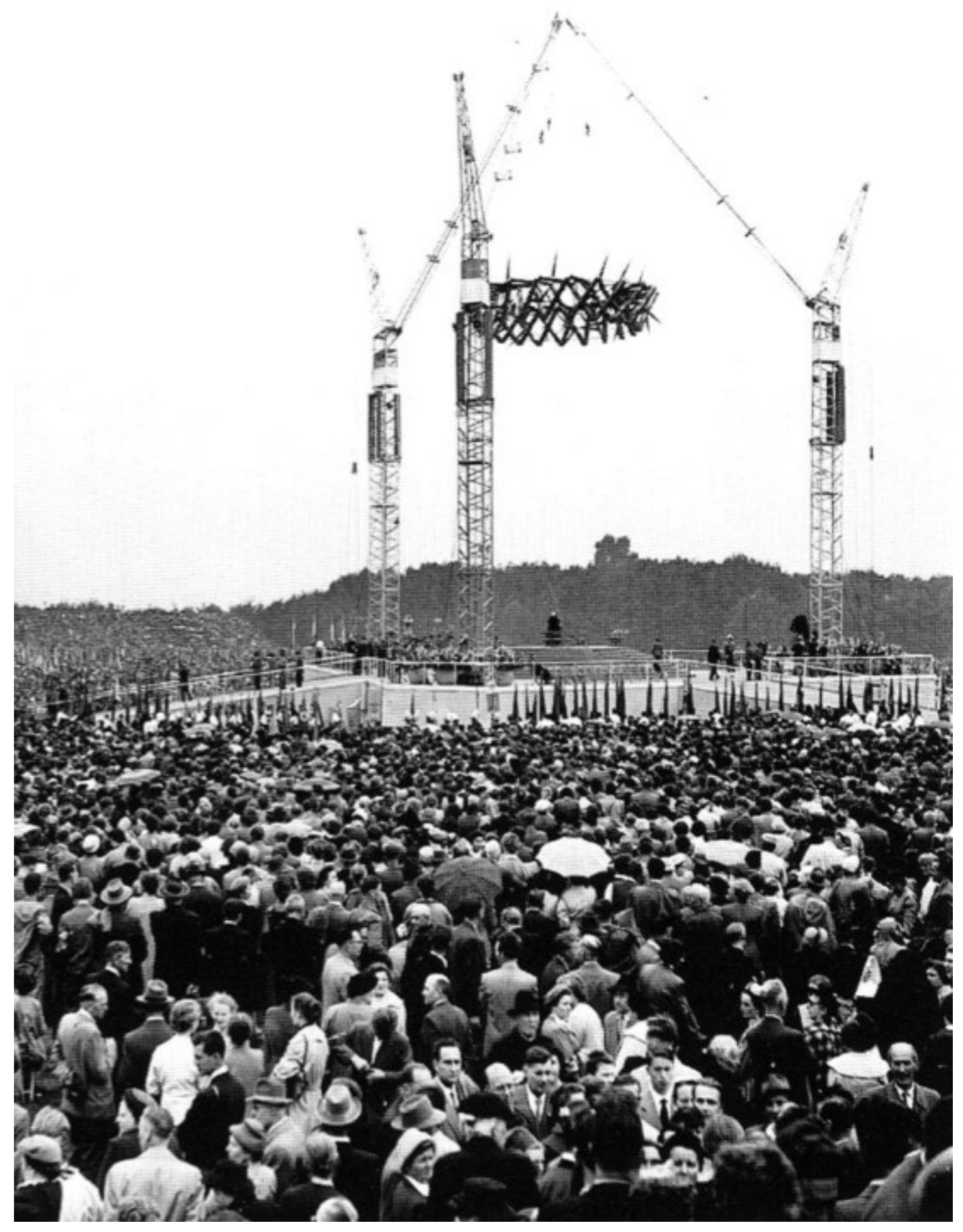

Fig. 9. Altar provisional para celebración de la eucaristía al aire libre Dornenkrone (corona de espinas), de Rudolf Schwarz y el escultor Theo Hiermann, 1956, Colonia. Fuente: Fernández Cobián 2000, p. 1169. 
Uno de los primeros casos de extrapolación de lo sagrado a lo profano a través del arte se la debemos al Romanticismo, que se solapó cronológicamente tanto con la Ilustración como con el Movimiento Litúrgico. La figura del pintor Caspar David Friedrich encabezó dicha empresa, llegando a afirmar: "la iglesia visible ha muerto. Solo queda la iglesia invisible, la que vive en el alma, o la que queda en la naturaleza”. Este artista inventó una pintura de paisaje en que este aparecía cargado de religiosidad. (Plazaola 1999, p. 140) Conseguía expresar la idea novedosa de que lo sacro estaba ya en el paisaje natural y que solo había que saber percibirlo. Se manifestaba a través del ideal estético de lo sublime, propio del Romanticismo.

Tanto las celebraciones de misas al aire libre como las iglesias al aire libre, que fueron habituales desde poco antes del Concilio Vaticano II, parecen tener en el arte del Romanticismo un precedente. Aunque ya se practicaban misas al aire libre algún tiempo antes del Concilio, como misas de campaña con altares portátiles, estas eran poco frecuentes y necesitaban permisos especiales. Esta situación cambió con la cercanía del Concilio Vaticano II, para lo que fue muy significativo que el acto de clausura consistiera en una misa en el exterior de la Basílica de San Pedro, en la plaza del Vaticano. No sería exagerado decir que ese acto fue una declaración de intenciones respecto al desbordamiento de la función litúrgica.

Paralelamente, en los años 60, con el desarrollo de diversos movimientos teatrales de vanguardia, como el Teatro de calle, el Teatro pobre o el Teatro sagrado, se generalizó la salida de las representaciones al espacio público, en general con fines políticos. El caso particular de la compañía norteamericana The Living Theatre tiene especial interés por la elección de los lugares para sus representaciones, siempre con una finalidad que sobrepasaba lo escénico para intentar influir en la realidad política y social. El uso del espacio utilitario de la vida común como espacio para la representación teatral es una constante para la compañía, para la que eran habituales sus representaciones en calles, parques y otros enclaves urbanos, con el objeto de lograr mayor impacto en la sociedad. (Granés 2015, p. 32)

Los ejemplos más conocidos y de mayor repercusión mediática de celebraciones efímeras al aire libre han sido los eventos multitudinarios organizados para las visitas de los Papas en varias ciudades. En Madrid se han realizado en la plaza de Colón. Estas eucaristías están relacionadas con las okupaciones del espacio público por parte del activismo en otros ámbitos. Hasta poco antes del Concilio Vaticano II, no se utilizaban espacios descubiertos para tales celebraciones. Por ejemplo, para la visita del papa Juan Pablo II en 1983 a Madrid se cubrió el estadio de fútbol Santiago Bernabéu; sin embargo, la siguiente visita se organizó en una plaza tan emblemática de Madrid como es la de Colón. Esa instalación tuvo un significado que superaba el simple utilitarismo. Sirvió para reivindicar un espacio y para visibilizar a un colectivo, como lo haría cualquier otro con fines políticos. (Fernández Cobián 2000, p. 662) 
Las iglesias cargadas de elementos profanos, como en las que se puede entrar con el coche al interior, o las que son descubiertas o móviles, ilustran la situación actual de intercambio y desplazamiento de las funciones sagradas y profanas. En cuanto al caso de la tipología norteamericana de las iglesias drive-in, como la Daytona Beach Drive-in Christian Church, instalada en un antiguo autocine (Fig. 10), es interesante que funcionan con normalidad pese a lo artificioso de escuchar la misa a través de un canal por la radio del coche y de estar en el espacio profano y vulgar del propio vehículo utilitario.

Durante la pandemia del SARS-Covid 19 las celebraciones drive-in han experimentado un nuevo esplendor, por las evidentes ventajas de distanciamiento social que proporcionan. Este es solo uno de la infinidad de desplazamientos espaciales de funciones arquitectónicas propiciados por la pandemia. En el ámbito de la religión católica, de obligada participación semanal en celebraciones colectivas con cercanía y contacto físico, se han hecho necesarios muy diversos desplazamientos. Muchos de ellos ya existían de forma incipiente o minoritaria.

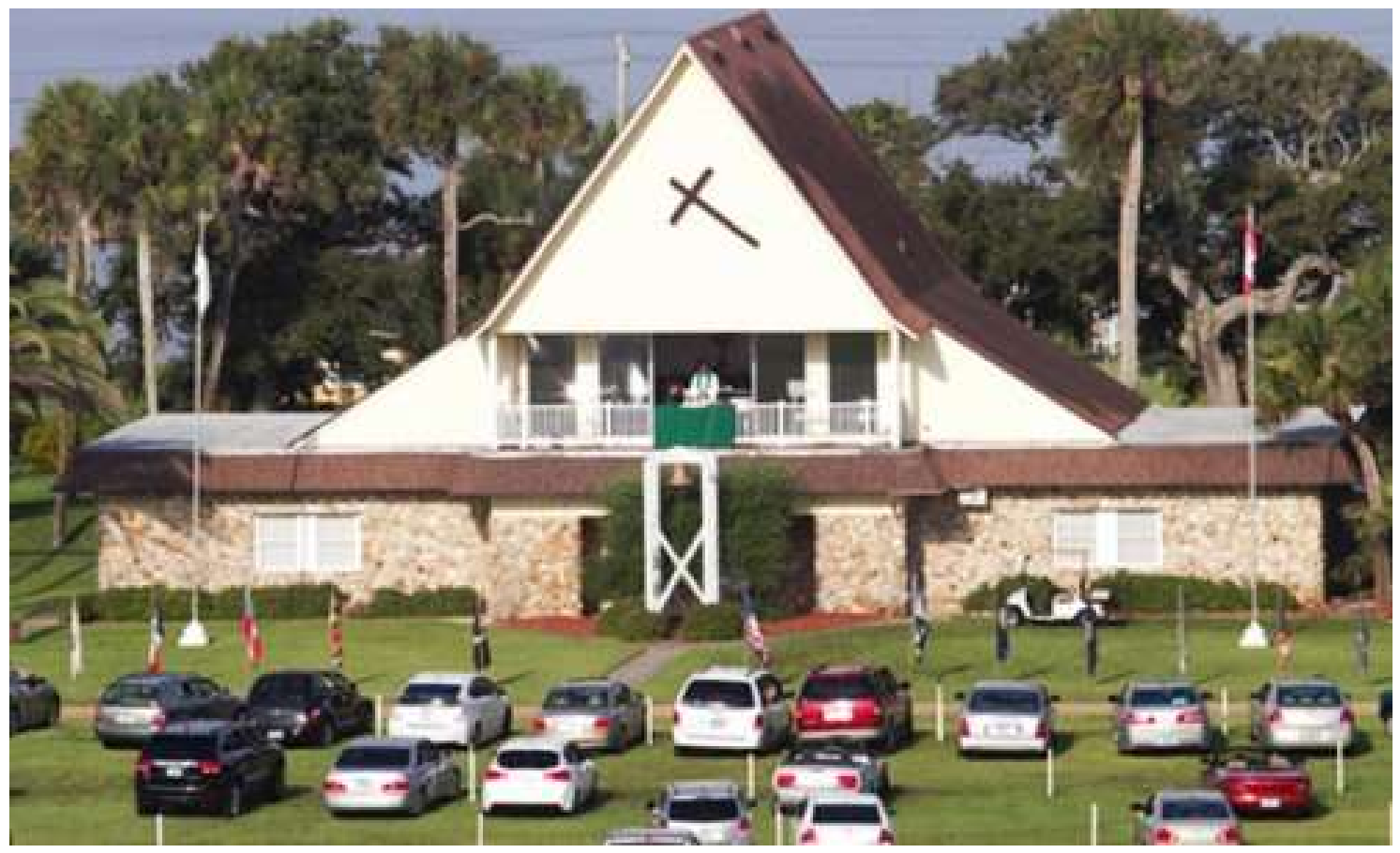

Fig. 10. Iglesia drive-in. Fuente: web de Daytona Beach Drive-in Christian Church: https://www.driveinchurch.net/

El caso de las iglesias al aire nos libre resulta más familiar, pero hay que señalar que fueron una tipología revolucionaria, aunque ya es muy antigua. En su origen estuvo motivada por la necesidad urgente de templos y fue favorecida por el buen clima de Méjico durante la Colonia Española. (Fernández Cobián 2000, p. 663) Se adelantó varios siglos a este 
proceso de emisión de lo sacro al mundo profano desde el espacio cerrado las iglesias. Durante unos dos siglos se dejaron de hacer casi por completo y después del Concilio Vaticano II se retomó la tipología como lo más natural del mundo, posiblemente porque que se habían normalizado los desplazamientos de funciones sacras y profanas dentro y fuera de las iglesias.

Un ejemplo más de desplazamiento de funciones sagradas en el espacio profano lo fue la iglesia móvil de la diócesis de Charleston (USA). Según consta en la página web de dicha diócesis, la iglesia móvil era un furgón reconvertido que fue usado para evangelizar en las zonas rurales Williamsburg County y otras partes del estado desde 1949 hasta 1967. (Fig. 11) Es un caso especialmente interesante porque el espacio sagrado se desplaza completo, en una especie de cápsula, a través del paisaje profano rural de Norteamérica. Aunque cabría preguntarse si queda todavía algún paisaje del todo profano, como adelantó el pintor Caspar David Friedrich.

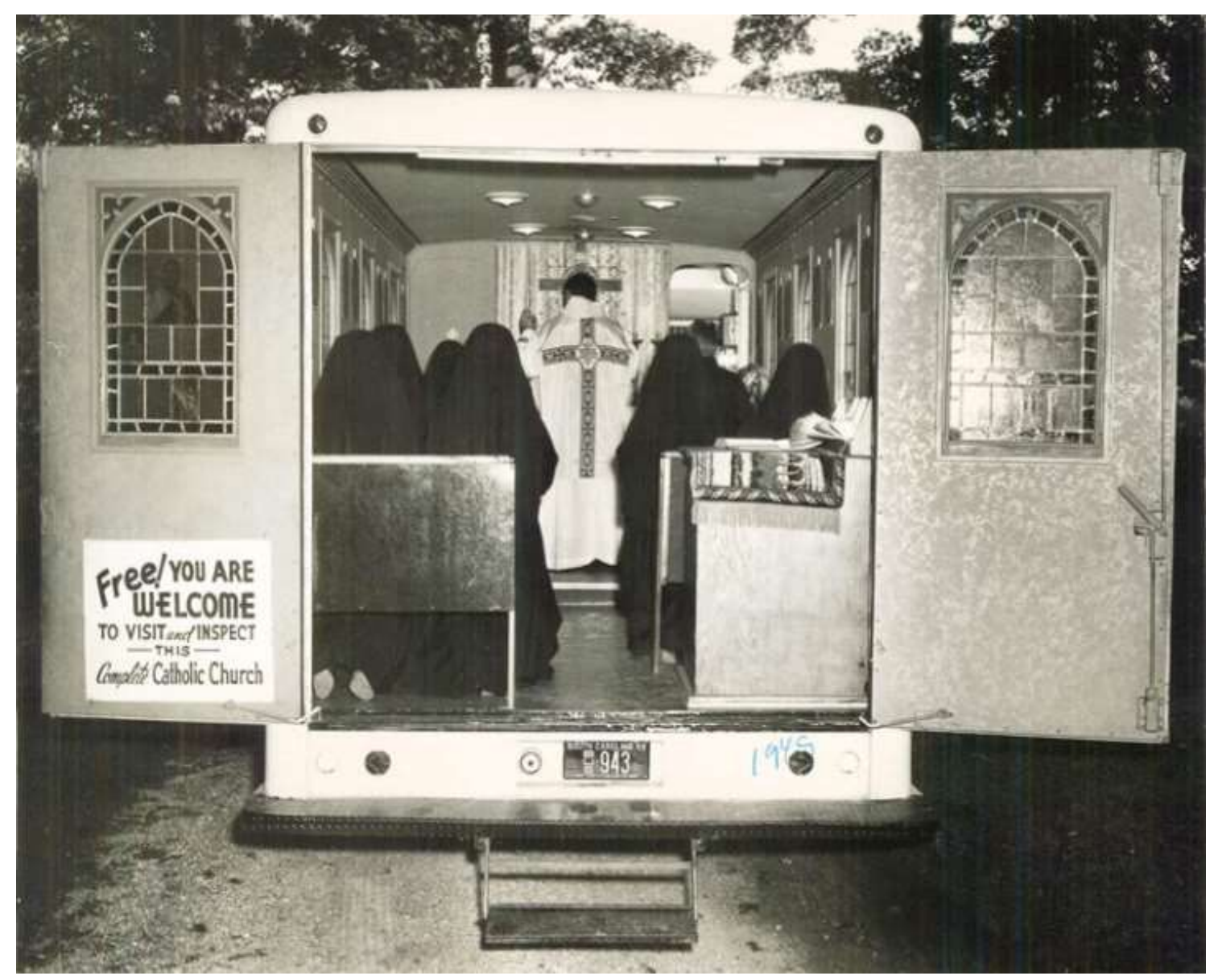

Fig. 11. "The church on wheels" Capilla móvil del padre dominico Patrick Walsh. Fuente: https://themiscellany.org/2015/05/28/historic-mobile-church-rediscovered/ 
Otros autores observan también una dispersión -o difusión- de determinados campos disciplinares en la totalidad de ámbitos de la realidad. En ese sentido, Boris Groys habla del "diseño total" (Groys 2013, p. 13) o Ernesto L. Francalanchi de la "estética difusa". (Francalanchi 2010,p. 14) En el caso de la religión, la fusión con la vida real es tan natural en nuestros días que se ha convertido en un recurso narrativo para el cine y la industria del entretenimiento. Un ejemplo -aunque no es liturgia católica- es la secuencia de la serie de ficción Ozark, de la plataforma Netflix, en la que una misa celebrada en pequeñas embarcaciones sobre un lago les servía a unos delincuentes para traficar con droga, alojándola dentro de los misales. (Fig. 12)

En cuanto a la deslocalización de las funciones sagradas, resulta especialmente interesante el creciente uso de Apps Católicas que, como otras incorporadas a la vida cotidiana, permiten simultanear el espacio analógico con el digital. Las aplicaciones incluyen acceso en vivo a eventos religiosos y cámaras web del Vaticano, tutoriales para rezar el rosario, etc. Como caso curioso, en la edición digital del periódico Nueva Colombia se recogía la noticia hace cuatro años: "a principios de 2017 se lanzará “The Catholic App” (...) La aplicación, presentada en un programa de radio del Vaticano, ya fue rebautizada por usuarios de redes sociales como Sindr, en referencia a Tinder y la palabra pecado en inglés". Cuatro años después se pueden encontrar decenas de aplicaciones gratuitas para instalar en el móvil y llevar lo sagrado en el bolsillo a cualquier parte.

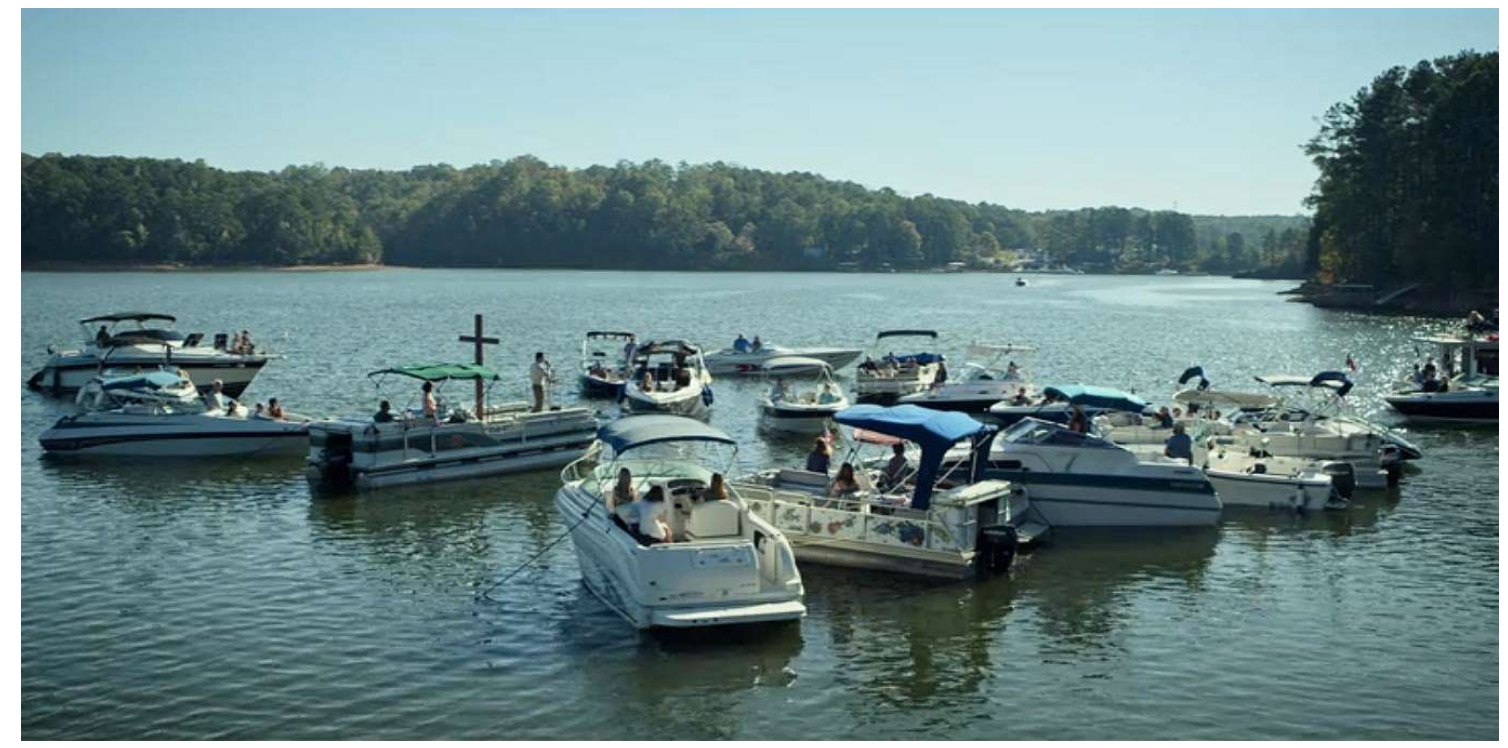

Fig. 12. Fotograma de la serie de ficción Ozark, de la plataforma Netflix. Fuente: Netflix 


\section{Conclusiones}

El arte y el teatro de las vanguardias operaron de forma creativa con la separación que menciona Agamben, lo que nos permite identificar determinados procesos de profanación, observados primero en el teatro, que se incorporaron a las iglesias. De manera que la reestructuración de los templos causada por la renovación de la liturgia, que culminó en el Concilio Vaticano II, implicó la incorporación de funciones del campo de lo profano al interior de las iglesias en correlación con los cambios en las salas de teatro. Dicha asimilación de elementos externos se sigue produciendo en la actualidad, como un proceso de transición desde lo analógico a lo digital, naturalizado en la última década

Con la renovación del teatro y de la liturgia, en teatros e iglesias se desplazaron las funciones de lugar para recuperar una autenticidad que se consideraba perdida y que muchos autores consideraban un reflejo de la irrealidad que, en todos los ámbitos, caracterizaría la vida en la sociedad moderna. Al principio los desplazamientos se dieron dentro de las propias salas o espacios de culto, pero más adelante se producirían migraciones a otros lugares totalmente nuevos y sin relación previa con los espacios tradicionales. En esos desplazamientos de los usos de los teatros e iglesias se puede detectar el empleo de recursos que había inventado el arte de las vanguardias históricas del Dadá y el Surrealismo, sobre todo como una práctica concreta de la técnica del ready-made que podríamos llamar arquitectónica o espacial, de marcado carácter político.

En el caso de la liturgia, se han producido desde mediados del siglo XX hasta nuestros días una serie de fenómenos que indican que no solo lo profano accede al espacio sagrado, sino que lo sagrado transita y ocupa el mundo de lo profano. La construcción de iglesias al aire libre, las celebraciones efímeras al aire libre, las misas televisadas, las iglesias drive-in, las iglesias móviles o las aplicaciones para dispositivos móviles de la Iglesia, son ejemplos de dispersión de la función litúrgica, que se difunde entre lo profano exterior a los templos católicos sin una clara delimitación funcional ni espacial.

La nueva definición de lo que debe ser la vida religiosa que propuso hace décadas la Iglesia, según la cual se desplegaría en el espacio-tiempo de lo cotidiano, incide en la dispersión descrita. Quedan así sacralizados, en determinadas dosis y distintos intervalos de tiempo - a menudo de manera difusa - los espacios tradicionalmente profanos. Del mismo modo que el diseño, según Groys, o la estética, según Francalanchi, se encuentran en mayor o menor medida en todo lo que constituye las sociedades actuales, cabría preguntarse si la religión tiene también ese carácter omnipresente, aunque pase desapercibido.

De la dificultad que existe para distinguir y deslindar con nitidez lo profano de lo sagrado, se deduce que la dualidad que formaban se fue desdibujando desde final de la Segunda Guerra Mundial hasta nuestros días. Las manifestaciones de todo ello en el espacio analógico o digital- hace tiempo que se dejan ver, aunque en general sean, por definición, tenues y ambiguas. 


\section{Referencias}

AGAMBEN, Giorgio. Profanaciones. Costa, Flavia y Castro, Edgardo (trad.). Buenos Aires: Adriana Hidalgo, 2005. ISBN 987-1 156-34-0

ARTAUD, Antonin. El teatro y su doble. Barcelona: Edhasa, 2015. 189 p. ISBN: 978-84- 350-1885-2

AUBERT, Roger, BRULS, J., CRUNICAN, P. E., TRACY ELLIS, J., HAJJAR, J. y PIKE, F. B. Nueva historia de la Iglesia. Tomo V. La Iglesia en el Mundo Moderno (1848 al Vaticano II). Muñoz Schiaffino, T. (trad.) Madrid: Ediciones Cristiandad, 1984. ISBN: 84-7057-223-7

BENJAMIN, Walter. El autor como productor: Aguirre, Jesús (trad.). Madrid: Taurus, 1975

BENJAMIN, Walter. La obra de arte en la época de su reproductibilidad técnica, México D.F.: Editorial Ítaca, 2003. 127 p. ISBN: $968-7943-48-3$

BROOK, Peter. El espacio vacío. Barcelona: Ediciones Península, 2012. ISBN: 10: 8499421423

CAPITEL, Antón. “Teología y funcionalismo. Las formas sagradas de Rudolf Schwarz”. Arquitectura Viva 58 enero-febrero 1998. Pág. 68-71. ISSN: 0214-1256

CORNAGO BERNAL, Óscar. La vanguardia teatral en España (1965-1975): del ritual al juego, Madrid: Visor, 2000. ISBN: 84-7522-848-5

DEBORD, Guy. La sociedad del espectáculo, Pardo, José Luis (trad.). Valencia: PRE-TEXTOS, 2009. ISBN: 97884-8191-442-9

DE A. LIMA, Zeuler R. M., Lina Bo Bardi, China: Regent Publishing Services Ltd., 2013

FERNÁNDEZ COBIÁN, Esteban. “El espacio sagrado en la arquitectura española contemporánea”. Director: José Ramón Alonso Pereira. Universidade da Coruña, Departamento de Construcciones Arquitectónicas, Coruña, 2000.

FERNÁNDEZ-COBIÁN, Esteban. El espacio sagrado en la arquitectura española contemporánea, Santiago de Compostela: Colexio Oficial de Arquitectos de Galicia, 2005. ISBN 84-85665-71-6

FERNÁNDEZ-COBIÁN, Esteban, 2016. Las partes de una iglesia y los modelos dimensionales. En: slideshare.net. Disponible en: https://es.slideshare.net/EstebanFernndezCobin/las-partes-de-una-iglesia-ylos-modelos-dimensionales

FRANCALANCI, Ernesto L. Estética de los objetos. Madrid: La balsa de la Medusa, 2010. ISBN: 9788477746973

GRANÉS, Carlos. La invención del paraíso. The Living Theatre y el arte de la osadía. Barcelona: Penguin Random House Grupo Editorial, 2015. ISBN: 978-84-306-0944-4

GRANÉS, Carlos. El puño invisible. México D.F. Santillana Ediciones Generales, 2011. ISBN ebook: 978-60711-1656-7

GROYS, Boris. Antología, Saúl Villa (Trad.). "La soledad del proyecto” Paloma Checa-Gismero y Saúl Villa (Trad.). México: COCOM Press, 2013. ISBN-978-607-9216-03-0. Disponible en: https://monoskop.org/images/c/c2/Groys_Boris_Antologia_2013_ES.pdf

INNES, Christofer. El teatro sagrado. El ritual y la vanguardia. Utrilla, Juan José (trad.) México: Fondo de Cultura Económica, 1992. ISBN 968-16-3778-X

KANT, Emmanuel. ¿Qué es la Ilustración?, en Foro de Educación, n. 11, 2009, pp. 249-254. ISSN: 1698-7799. Disponible en: https://dialnet.unirioja.es/servlet/articulo?codigo $=3171408$

Transcripción de texto original: KANT, E. Filosofia de la Historia. Madrid: Fondo de Cultura Económica, 2000, 25-37.

LABOA, Juan María. Historia de la iglesia IV. Época contemporánea. Madrid: Biblioteca de Autores Cristianos, 2002. ISBN: 84-7914-601-X 
GARCÍA-ASENJO LLANA, David. "Estrategias de proyecto en la arquitectura sacra contemporánea española”. Director: Valentín Berriochoa Sánchez-Moreno y Víctor Olmos Gómez. Universidad Politécnica de Madrid, Departamento de Proyectos Arquitectónicos, Madrid, 2016.

NAVARRO DE ZUVILLAGA, Juan. Homenaje a Alfred Jarry en el centenario del estreno de Ubu Rey. Madrid: Javier Navarro de Zuvillaga (Editor), 1997.

PARSCH, Pius. The liturgy of the mass. Rev. C. Eckhoff, Frederic (trad.). Londres: B. Herder Books, 1940.

PLAZAOLA, Juan. El arte sacro actual. Estudio. Panorama. Documentos. Madrid: Editorial B.A.C., 1965.

PLAZAOLA, Juan. Historia del arte cristiano. Madrid: Editorial B.A.C., 1999. ISBN: 84-7914-427-0

PRIETO LÓPEZ, Juan Ignacio. “La revolución teatral soviética”. Las puertas del drama. № 48. 2017. Disponible en: http://www.aat.es/elkioscoteatral/las-puertas-del-drama/drama-48/la-revolucion-teatral-sovietica/

RAMÍREZ, Juan Antonio. Edificios-cuerpo. Madrid: Ediciones Siruela, S.A., 2003. ISBN: 84-7844-706-7

RODRÍGUEZ ADRADOS, Francisco. Teatro y religión. En Revista de dialectología y tradiciones populares, ISSN 0034-7981, Tomo $\quad 49, \quad$ Cuaderno $\quad 1, \quad$ 1994, págs. 5-24. $\quad$ DOI: http://dx.doi.org/10.3989/rdtp.1994.v49.i1.277

VIDLER, Antony. Ledoux. Calatrava, Juan A. (trad.) Madrid: Ediciones Akal, S.A., 1994. ISBN: 84-460-0310-4

WILTGEN, Ralph M. El Rin desemboca en el Tíber. Historia del Concilio vaticano II. Madrid: Criterio Libros, 1999. ISBN: 84-923838-9-5 


\section{Bio}

Julio César Moreno Moreno. Arquitecto, Máster en Proyectos Arquitectónicos Avanzados por la Universidad Politécnica de Madrid. Profesor asociado de Proyectos Arquitectónicos en la Universidad Rey Juan Carlos. De 2006 a 2014 docente de Proyectos Arquitectónicos en la Universidad Pontificia de Salamanca, Campus de Madrid. Doctorando en la Escuela Técnica Superior de Arquitectura de Madrid, UPM. Miembro del Grupo de investigación Teoría y Crítica de la Arquitectura Moderna y Contemporánea ETSAM, UPM. Ha publicado artículos sobre desplazamientos de la función en la arquitectura y en el arte, y sobre sus implicaciones políticas, tema de su tesis doctoral en redacción.

\section{Bio}

Julio César Moreno Moreno. Architect, Master in Advanced Architectural Projects from the Polytechnic University of Madrid. Associate Professor of Architectural Projects at the Rey Juan Carlos University. From 2006 to 2014 lecturer in Architectural Projects at the Pontifical University of Salamanca, Madrid Campus. PhD candidate at the Madrid School of Architecture, UPM. Member of the research group Theory and Criticism of Modern and Contemporary Architecture ETSAM, UPM. He has published articles on displacement of function in architecture and art, and on their political implications, the subject of his doctoral thesis in writing. 